\title{
WestVirginiaUniversity
}

THE RESEARCH REPOSITORY @ WVU

Graduate Theses, Dissertations, and Problem Reports

2009

\section{The dating game: Cultivation effects on relational investment}

Thomas L. Meade

West Virginia University

Follow this and additional works at: https://researchrepository.wvu.edu/etd

\section{Recommended Citation}

Meade, Thomas L., "The dating game: Cultivation effects on relational investment" (2009). Graduate Theses, Dissertations, and Problem Reports. 770.

https://researchrepository.wvu.edu/etd/770

This Thesis is protected by copyright and/or related rights. It has been brought to you by the The Research Repository @ WVU with permission from the rights-holder(s). You are free to use this Thesis in any way that is permitted by the copyright and related rights legislation that applies to your use. For other uses you must obtain permission from the rights-holder(s) directly, unless additional rights are indicated by a Creative Commons license in the record and/ or on the work itself. This Thesis has been accepted for inclusion in WVU Graduate Theses, Dissertations, and Problem Reports collection by an authorized administrator of The Research Repository @ WVU. For more information, please contact researchrepository@mail.wvu.edu. 
The Dating Game: Cultivation Effects on Relational Investment

\author{
Thomas L. Meade
}

\author{
Thesis submitted to the \\ Eberly College of Arts and Sciences \\ at West Virginia University \\ in partial fulfillment of the requirements \\ for the degree of
}

\author{
Master of Arts \\ in \\ Communication Studies \\ David Westerman, Ph.D., Chair \\ Brian Patterson, Ph.D. \\ John Cole, M.A. \\ Department of Communication Studies
}

\author{
Morgantown, West Virginia \\ 2009
}

Keywords: Cultivation Theory; Investment Model; Alternatives; Relationship; Television

Dating; Relational Investment

Copyright 2009 Thomas L. Meade 


\section{ABSTRACT \\ The Dating Game: Cultivation Effects on Relational Investment}

\section{Thomas L. Meade}

This study investigated the relationship between high exposure to reality television dating shows (Rock of Love, The Bachelorette, etc) and higher perceptions of alternatives to a current romantic relationship as explained by Cultivation Theory (Gerbner \& Gross, 1973) and the Investment Model (Rusbult, 1980). This study employs interpersonal communication strategies to study media effects. Surveys were collected from 273 students at a large university. Results indicate higher exposure to reality television dating shows may cultivate a higher perception of alternatives to a current romantic relationship, however do not cultivate a belief that one's partner believes themselves to have a high perception of alternatives. Various covariates are also tested including love styles and the perceived reality of television. Limitations and directions for future research are also discussed. 


\section{ACKNOWLEDGEMENTS}

I would like to thank everyone who helped and encouraged me throughout this project. First of all, thank you Dr. Westerman for guiding me through my first big research project. Your constant direction and support was always appreciated. Thank you for enduring the many e-mails and my complete commandeering of your Monday office hours this semester, though I always enjoyed it.

Thank you to all those on my committee. Thank you for the guidance and the learning opportunity, but also many thanks for making the defenses more fun than they were nerveracking. I always appreciate a good laugh.

Thank you to all of my family, who have always been there for me. Thank you to all of my closest friends, especially to Colleen Malachowski, whom without, I may not have made it through this undertaking. Thank you to my professors and all my colleagues as well. It has truly been an honor to work with everyone. 


\section{TABLE OF CONTENTS}

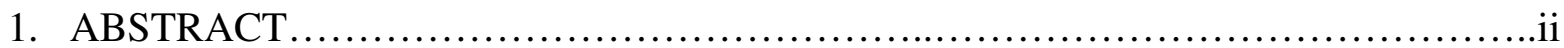

2. ACKNOWLEDGEMENTS .........................................................

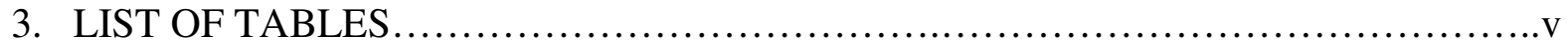

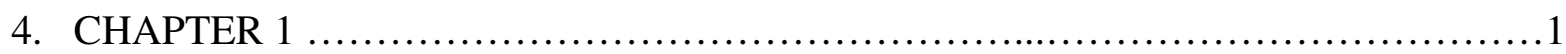

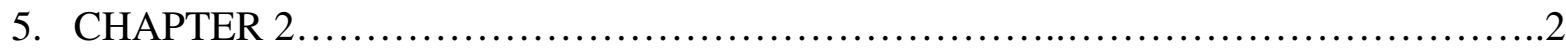

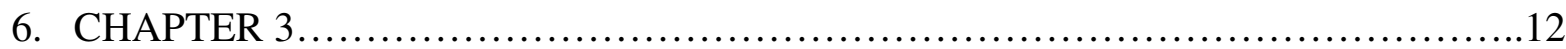

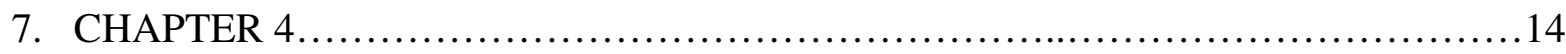

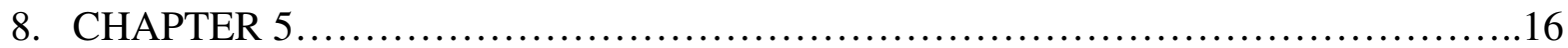

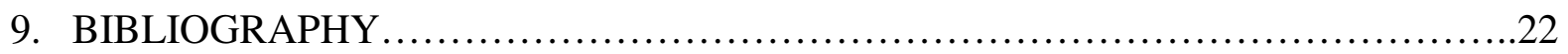

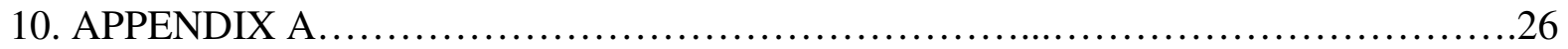

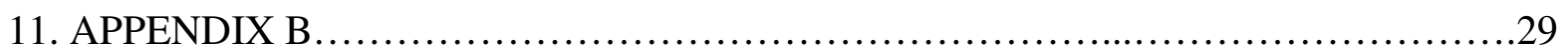

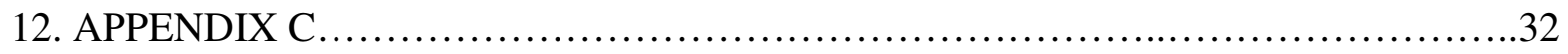

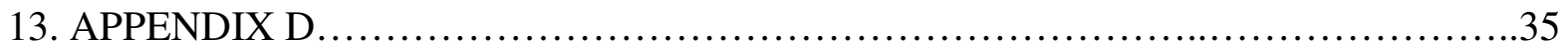

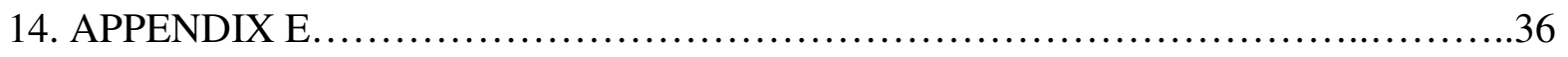

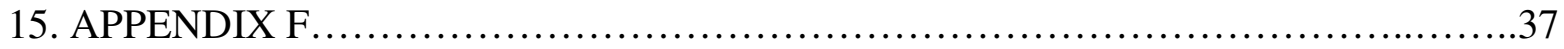

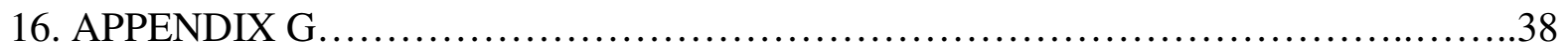

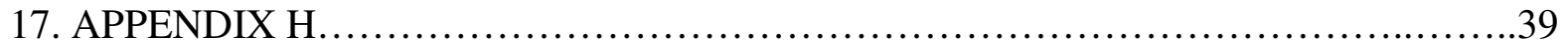

18. CURRICULUM VITAE ............................................................ 40 


\section{LIST OF TABLES}

1. Correlations Between Various Alternatives Scales and Exposure..........................36

2. Correlations Between Love Styles and Exposure and Affinity/Involvement..................37

3. Significant Variables Accounting for Variance in Perceived Alternatives....................38

4. Correlation Matrix of All Variables.................................................... 39 


\section{CHAPTER 1 INTRODUCTION}

The Dating Game: Cultivation Effects on Relational Investment

The fields of interpersonal communication and media effects intersect across various avenues. In fact, one of the potentially strongest effects media may have is on shaping interpersonal relationships (Borisoff, Hoel, \& McMahan, 2009). Media, especially television, can potentially influence our lives in many ways, and has been shown to create and shape our opinions and expectations of the world around us, including expectations of personal relationships (Segrin \& Nabi, 2002). According to Cultivation Theory, the more one watches television, the more one interprets it as the real world (Gerbner \& Gross, 1973). Many relationships depicted on television are interpersonal in nature. Therefore, media portrayals may influence many interpersonal interactions. One such interaction is dating.

Various types of media content depict individuals with many alternatives to relationships. One such example is television dating shows in which one individual has to choose from many alternatives. Do individuals that watch television dating shows perceive themselves to have higher alternatives to their relationship? This study will look at how cultivation processes operate to create expectations about interpersonal relationships. This paper examines the potential relationship between entertainment portrayals and people's perceived options in their own relationships. It does so by articulating cultivation theory, and its potential role in the Investment Model. 


\section{CHAPTER 2 REVIEW OF LITERATURE}

\section{Cultivation Theory}

Cultivation Theory implies that the more one is immersed in media content, especially television, the more one will believe what is depicted is what exists in the real world (Gerbner \& Gross, 1973). In other words, if an individual watches a lot of television, that individual is more likely to think that it depicts the way the world works. Cultivation Theory also implies that one will apply the knowledge gained from the television world to the real world. Therefore, what an individual sees on television will be assumed to be true for the real world, and, when placed in similar situations to what is presented on television, an individual will call on the experience gained from the immersion in television to solve or deal with that similar situation (Gerbner \& Gross, 1973). Over time, after an accumulation of television messages, an individual will supplant real world experience for television experience, and will therefore deal with situations as they have been taught by their television experiences. Thus, television will be especially powerful when real world experience is lacking. Humans have a tendency to use experience to categorize future events and may replace real life experience with television "experience". And thus, humans use the "experiences" gained from television to categorize and deal with real life events and situations, leading to beliefs about the real world that are cultivated from television. This is what Cultivation Theory suggests in its simplest form.

As Cultivation Theory has been a guiding theory for mass communication research for nearly 40 years, it has also been criticized and adapted throughout its history. For example, Wober and Gunter (1988) found that television cultivation tended to be program specific. Individuals that viewed programming depicting inner-city violence tended to have a greater fear of inner-city violence rather than rural violence, or violence as a whole. This suggests that what 
viewers watch is as important as (if not more so) how much they watch, and thus, specific types of content can cultivate particular viewpoints in viewers.

Viewing certain types of media content has also shown that it can have influences on expectations in interpersonal relationships. For example, Zillman (1986) found that exposure to pornography impacted viewer's judgments of their own relationships. As Zillman states: "Prolonged consumption of common pornography breeds discontent with the physical appearance and the sexual performance of intimate partners. To a lesser degree, it breeds discontent with these partners' affectionate behavior (p. 27)."

Specifically, Zillman and Bryant have found that massive exposure to pornography over time leads to viewer's increased perceptions that various sexual behaviors were more likely in the real world (Zillman, 1986), lower levels of satisfaction in one's own sex life (Zillman \& Bryant, 1988), and more lenient attitudes toward sexual violence (Zillman \& Bryant, 1982). These studies, taken together, provide evidence that exposure to specific types of content can influence people's own relationships.

Particularly interesting for the current study is the research suggesting that exposure to pornography reduces one's satisfaction with one's own sexual partner. The reasons offered for this look at the way relationships are portrayed commonly in pornography. The researchers suggest that consistently viewing people having sexual intercourse with multiple partners creates expectations about sex in the real world happening similarly. It also creates expectations about the alternatives that exist for sexual partners in the real world. This potential for certain types of media to create expectations about alternatives for viewers leads to two questions: 1) can this happen for other types of media content, especially content that also presents relationships as a 
game of choosing among alternatives, and 2) how can the Investment Model (Rusbult, 1980) inform this type of study?

\section{Investment Model}

According to Social Exchange Theory (Blau, 1964), human behavior is driven by costs and rewards. The main goal is to maximize rewards at the lowest cost. How an individual will react to a situation is dependent upon their analysis of the rewards and costs. If rewards are not perceived as lower than cost, people have a tendency to be satisfied with that specific situation. This may also be true of romantic relationships, as supported by the Investment Model.

The Investment Model (Rusbult, 1980) is an interpersonal relational model that focuses mainly on rewards and costs. A relationship of any sort will be seen as satisfying or dissatisfying, depending on various factors. The Investment Model suggests that as the costs of the relationship go down, the satisfaction level with the relationship will go up. In other words, individuals are happiest with a relationship in which rewards are maximized at the lowest cost. The Investment Model measures this cost-benefit analysis through four predictors: satisfaction, commitment, investment, and the perceived quality of alternatives. Therefore, the Investment Model is a form of Social Exchange Theory in interpersonal, romantic relationships. As the costs of the relationship get higher, satisfaction, or reward is lower.

The satisfaction of the relationship is measured as an amalgamation of all four predictors. The satisfaction will get higher as commitment is higher, investment is higher, and the perceived quality of alternatives is low. Commitment is defined as how strongly the individual wishes to stay in the relationship. Commitment will be high when investments are high and the perceived quality of alternatives is low. Investment in a relationship is defined as what an individual may give up to be in the relationship, or how much time and effort they have put into the relationship. 
Investment will tend to get higher as perceived quality alternatives are given up, for example, or investment will be higher the longer the relationship lasts. The perceived quality of alternatives is in reference to how the individual views the desire to be with another person or be alone. For example, an individual may know another person they would rather be in a relationship with, and, if that person is also interested, they may give up their current relationship to pursue another; if they feel the other relationship is of greater worth to them (Rusbult, 1983).

Alternatives and satisfaction do not always predict commitment to a relationship, however, as investment may be a most telling predictor of commitment. Many individuals may find themselves to be in a relationship of some sort in which they are not happy with some particular aspect (Rusbult, 1980). For example, one may be in a relationship where they find many others to be a much better alternative, however, they are married with children to a certain individual. Though the alternatives are high, the investment is higher, and therefore may be a greater predictor of commitment. Alternatives may be a better predictor when less is invested in a relationship. And, though alternatives may not be the most telling predictor of commitment, they still play a large role (Rusbult, 1980). Rusbult (1983) found that an increase in commitment was directly related to a decline in alternatives. College students, therefore, make for an excellent sample. These individuals see many alternatives on a daily basis, and generally move from partner to partner, with less invested in a relationship. Less investment leads to a greater role for perceived alternatives in overall commitment (Rusbult, 1980).

Commitment has much to do with relationship stability. A romantic relationship that suffers from low commitment will likely be ended. Commitment is found to be especially important in romantic relationships (Le \& Agnew, 2003), and can account for the reasons behind 
many stabilizing behaviors in a relationship, including controlling jealousy and a willingness to make sacrifices (Rusbult \& Buunk, 1993).

Rusbult, Zembrodt, and Gunn (1982) studied the Investment Model on four different relational outcomes to transgression, or threats to relationship stability and commitment. These four relational situations were "exit" (p. 1231), or ending the relationship, "voice" (p. 1231), or talking out the problems, "loyalty" (p. 1231), or simply hoping for the relationship to take a turn for the better with no action, and finally, "neglect" (p. 1231), or ignoring the situation and the partner, or adding to the downward turn the relationship has taken. The quality of relationship alternatives was seen to be connected with exit, suggesting that higher perception of relationship alternatives will lead to lower levels of commitment. Therefore, the perceived quality of alternatives has a role in the success of the relationship.

A change in perception of the quality of alternatives after having been subjected to a media may be a signifier of an overall change in identity construction over time. Identity will change throughout the life cycle and is open to outside influence (Erikson, 1968). Therefore, constantly being subjected to media of this type could affect the construction of identity, and may affect the relationships in which one partakes.

It has been found that a female's view of alternatives at the beginning of a relationship may predict the status of the relationship six months later. Females with lower quality alternatives at the beginning of a relationship normally predicted a stronger, more positive relationship after six months (Sacher \& Fine, 1996). Studies such as this, and many others supporting the Investment Model and the importance of the quality of alternatives to relationships (i.e. Rusbult, Johnson, \& Morrow, 1986; Guerrero \& Bachman, 2008), make it necessary to study the effect television has on our perception of quality alternatives to 
relationships. Television is more easily accessible by the day, and is therefore becoming a growing influence on our culture and decisions. As it plays more of a role in our lives, it is possible that television may have an increased influence on our thoughts about romantic relationships.

The Investment Model has been recently used to study such traits as jealousy (Bevan, 2008) and narcissism (Foster, 2008) and is mainly used as a model to study interpersonal relationships, be it romantic, friendly, or business. The model has been very lightly studied in regard to television, and has been mostly studied in regards to business when done so (i.e. Scott, Gobetz, \& Chanslor, 2008; Tuten, 2005). Therefore, the Investment Model produces many new frontiers to study television. According to the model, perceived alternatives play a large role in our commitment, whether it is by a perceived investment, or simply dissatisfaction with the relationship entirely (Rusbult, 1980). According to Cultivation Theory (Gerbner \& Gross, 1973), television may cultivate people to expect large amounts of seemingly viable, however more than likely not possible, alternatives and comparisons for a romantic relationship. This study will try to uncover the role perceived media-suggested alternatives play in romantic relationships.

An individual in a romantic relationship has an idea of what they would like to receive from the relationship, what they hope to get out of it, or what they feel they deserve from their relationship. This viewpoint is based on comparisons, or alternatives, that they have perceived from the outside world. From what they have gathered from the outside world, a person can gauge their own worth, and perhaps the worth of their partner. This worth is then put into an exchange process-type thought. Individuals will compare what they have in their partner with their own worth. They will then determine which they feel is of higher worth. If their partner is worth more than what they feel they are worth, they will stay. If their partner is worth less, they 
will leave. (Attridge \& Berscheid, 1994). The perception of alternatives comes from learning through the environment or past experience what an individual or that individual's partner may be worth. Individuals may get their perception of alternatives from anywhere; therefore the purpose of this study is to test if television has a part in cultivating that.

Attridge and Berscheid (1994) report that the individual's will to stay in a relationship is dependent mostly on their satisfaction with the relationship outcome in comparison to what else the individual may perceive to be an available relationship outcome. Those who stay in relationships will be mostly satisfied and committed based on what they perceive are the best alternatives to the relationship; therefore, alternatives to a relationship are a predictor of relationship satisfaction or commitment. An individual viewing television may identify with the main character or the main character's situation. If an individual identifies with the main character in some way, they may see themselves in that character and therefore may transfer the main character's abilities and alternatives to their own, making their perception of alternatives higher (Johnson, 2007).

Television can change how some people see their intimate relationships, even those who are married. In a study regarding popular romantic media and relationship satisfaction, Shapiro and Kroeger (1991) found that those who scored higher on a test of knowledge of popular romantic media also were found to be less satisfied with their relationships. Therefore, popular media has been shown to have a significant effect on how an individual feels about their relationship. This study is consistent with Cultivation Theory, in that the more knowledge an individual had regarding romantic media, the less likely they were to be satisfied with their relationship. Perhaps this romantic media cultivated an idea that led to their view of the relationship being unsatisfactory. 
Holmes (2004) found that media can have immediate effects on relationship satisfaction. Immediately after viewing a film about destiny, the participants were more likely to believe that a relationship is based on destiny. Another study within the same report found that the more a participant viewed media, the more they idealized their needs from a partner. Also, men who were exposed to erotic media were found to be less satisfied with their relationship because their ideals were not met. Over time, these individual's perceptions of needs from their partner were cultivated from these media, as were lower levels of relationship satisfaction. Could perceived alternatives also be cultivated through higher exposure to television dating shows?

Nabi (2009) found that reality television cultivated ideals in individuals. Specifically, that watching shows highlighting cosmetic surgery made individuals less satisfied with their bodies and more eager to get cosmetic surgery themselves. Nabi's (2009) study, in particular, may be seen as an excellent predictor for this study, as it showed a relationship between body satisfaction (here, relationship satisfaction) and viewing reality cosmetic surgery shows (here, reality dating shows). Given that Zillman (1986) found pornography to have strong effects on relational expectations, Holmes (2004) found that high exposure to certain media idealizes needs from a partner, and Nabi (2009) connected Cultivation Theory to reality television, all with similar results, this study can forward the first of two hypotheses:

H1: Individuals who watch a higher amount of television dating shows (i.e. The Bachelor, The Bachelorette, Rock of Love, etc.) will believe themselves to have higher alternatives to their relationship status.

Because the aforementioned studies supported cultivation, it may be possible that individuals view reality television dating shows and cultivate other expectations about relationships as well. That is, these shows may cultivate the idea, in individuals who watch a higher amount of 
television dating shows, that their partner is identifiable with the stars of the show. If this is true, they may begin to believe that their partner believes themselves to high alternatives to the relationship. For example, the individual watching a high amount of television dating shows may identify themselves as a contestant, and they may see their partner as the star, who chooses between the contestants. This may cultivate the idea that their partner believes themselves to have many alternatives to the relationship. This has unknown effects on the relationship itself. Cultivation Theory (1973) states that the more an individual watches, the more they believe television to depict the real world. Therefore, hypothesis two is forwarded:

$\mathrm{H} 2$ : Individuals who watch a higher amount of television dating shows will believe their partners to have a higher amount of alternatives to their relationship status.

Love styles are the categorization of the way in which an individual is attached to their partner (Hendrick, Hendrick, \& Dicke, 1998). Humans may become attached and love their partners in different ways. These different love styles may be a product of personality, experience, etc. (Hendrick et al., 1998), therefore, love styles may help to explain individual's affinities or involvement in television programming. Love styles have been shown to effect many areas of individual's personalities and lives such as partner engagement (Frey, \& Hojjat, 1998), communication skill values (Kunkel, \& Burleson, 2003), and partner preferences (Levine, Aune, \& Park, 2006).

Love styles may help to predict why certain individuals are attracted to television dating shows. There are six types of love styles: Eros, Ludus, Storge, Pragma, Mania, and Agape. Eros lovers tend to be passionate, sexual, and attentive lovers. Ludus lovers tend to look at love as a game. Storge lovers tend to create and base love in deep friendship. Pragma lovers are practical 
lovers, looking for the highest benefit. Mania lovers tend to be overly obsessive lovers. Finally, Agape lovers put their significant other's welfare above their own (Hendrick et al., 1998).

By learning which styles are most attracted to these shows, it may help to explain why and how certain individuals cultivate effects by watching. In other words, a certain type of love style may identify more so with the characters, and therefore may be more apt to view the show as real life. It may be interesting to measure the relation between each love style and each Investment Model measure. It may also be interesting to measure how the newly developed Partner's Alternatives Scale relates to Investment Model principles. However, research is lacking in this area, which leads to our research question:

RQ: Which love styles are most attracted to television dating shows? 


\section{CHAPTER 3 TEXT OF INVESTIGATION}

\section{Method}

\section{Participants}

Participants in this study included 273 students (118 men, 153 women) enrolled at a large Mid-Atlantic university. The age of participants ranged from 18 to $45(\mathrm{M}=21.03, \mathrm{SD}=2.43)$. $14.7 \%$ were freshman, $15.8 \%$ were sophomores, $31.5 \%$ were juniors, $33.7 \%$ were seniors, and $4.4 \%$ were other or did not report. Relationship length ranged from one month to 29 years $(\mathrm{M}=$ 19.41 months, $\mathrm{SD}=26.64$ months). $69.2 \%$ considered themselves to be seriously dating, $23.4 \%$ considered themselves to be casually dating, $3.3 \%$ were engaged, $2.2 \%$ were married, and 1.8 $\%$ were just fooling around. $92.3 \%$ were Caucasian, $2.9 \%$ were African American, $1.8 \%$ were other or did not report, $1.5 \%$ were mixed ethnicities, $0.7 \%$ were Asian American, $0.4 \%$ were Latino, and $0.4 \%$ were Native American.

\section{Procedure}

Students were informed of this study in a large lecture classroom. They were told they will receive extra credit if they participate. The primary investigator explained that the study is voluntary and it would not harm them in any way if they participate or do not participate. They were informed that the study looks at the relationship between the perceived quality of alternatives and an individual's consumption of television dating shows. The participants were then given an internet address to go to and fill out the survey at their convenience. For some, the website was also e-mailed, for others, the website was also posted on an online bulletin board frequented by these individuals. They were informed that they had two weeks to complete the survey. 


\section{Measures}

The survey consisted of four short questionnaires. One questionnaire studied participant's television habits in regard to television dating shows $(\alpha=.86)$, measuring their affinity for the shows, their exposure, and finally their involvement in the shows, this is regarded as the Affinity/Involvement Scale (Appendix A), another questionnaire measured the Investment Model (Appendix B; Rusbult, Martz, \& Agnew, 1998); specifically, the participants’ commitment to a relationship $(\alpha=.92)$, their perceptions of alternatives $(\alpha=.92)$, and the attitudes the participants have regarding their partner's feelings about their partner's relationship alternatives $(\alpha=.94)$, a third measured the individual's Love Style (Appendix C; Hendrick, et al., 1998), meant to measure how an individual views a romantic relationship. This scale was broken into the six love styles Eros $(\alpha=.90)$, Ludus $(\alpha=.78)$, Storge $(\alpha=.90)$, Pragma $(\alpha=.82)$, Mania $(\alpha=.82)$, and Agape $(\alpha=.87)$. Finally, a perceived reality questionnaire $(\alpha=.87$, Appendix D) measured how real an individual feels that television shows really are (Rubin, Perse, \& Taylor, 1988). 


\section{CHAPTER 4 SUMMARY AND CONCLUSIONS}

\section{Results}

Hypothesis one forwarded a significant relationship existed between exposure to television dating shows and the belief of having higher amounts of alternatives to the current relationship. Results show a significant Pearson correlation between time spent watching reality dating shows and perceived alternatives to one's relationship $(\mathrm{r}=.13, \mathrm{p}=.03)$. Thus, data is consistent with hypothesis one (Appendix E).

Hypothesis two forwarded a significant relationship between exposure to television dating shows and participant's beliefs that their current relationship partner believes they have higher amounts of alternatives to the participant. Results of a Pearson correlation indicate that this relationship is not significant $(\mathrm{r}=.04, \mathrm{p}=.56)$. Thus, data are not consistent with hypothesis two (Appendix E).

The research question asked if a relationship existed between any of the love styles and exposure to television dating shows. Results of a Pearson correlation indicate there is no significant relationship between any love style and exposure $($ Eros: $\mathrm{r}=-.02, \mathrm{p}=.72$; Ludus: $\mathrm{r}=$ $.11, \mathrm{p}=.07 ;$ Storge: $\mathrm{r}=.03, \mathrm{p}=.60$; Pragma: $\mathrm{r}=.11, \mathrm{p}=.08$; Mania: $\mathrm{r}=.11, \mathrm{p}=.06$; Agape: $\mathrm{r}=$ $-.05, \mathrm{p}=.39)$. The research question also asked if a relationship existed between any of the love styles and the Affinity/Involvement Scale. Results of a Pearson correlation indicate a significant relationship existed for Pragma $(r=.17, \mathrm{p}=.01)$ and Mania $(\mathrm{r}=.24, \mathrm{p}<.001)$. No other significant relationship existed (Eros: $\mathrm{r}=-.03, \mathrm{p}=.62$; Ludus: $\mathrm{r}=.05, \mathrm{p}=.43$; Storge: $\mathrm{r}=.07, \mathrm{p}$ $=.29 ;$ Agape: $\mathrm{r}=.03, \mathrm{p}=.66)($ Appendix F).

Overall, it was supported that television dating shows cultivate beliefs of higher alternatives. However, they do not cultivate beliefs that their partner perceives higher 
alternatives. It was found that Pragma and Mania love styles tend to have a higher affinity/involvement in television dating shows; however no other love style was correlated with exposure to or affinity/involvement for television dating shows (A correlation matrix can be found in Appendix H).

Post hoc Analysis

In order to more fully test the impact of watching television dating shows on people's perceived relational alternatives, a regression analysis was conducted, with perceived alternatives as the dependent variable (Appendix G). Independent variables included time spent watching dating shows and affinity for them, but also included each of the six love styles, length of relationship, seriousness of the relationship, and perceived reality of television. Even when including these other variables, time spent watching television dating shows had a significant relationship with perceived alternatives $(\beta=.13, \mathrm{p}=.02)$. Other variables with significant relationships to perceived alternatives included seriousness of relationship $(\beta=-.19, \mathrm{p}=.002)$ and perceived reality $(\beta=.11, \mathrm{p}=.05)$. This means that people in more serious relationships perceived fewer alternatives to that relationship and those who perceived television as more real also perceived more alternatives to their current relationships. Of love styles, only Ludus ( $\beta=$ $.27, \mathrm{p}=.00)$ and Eros $(\beta=-.32, \mathrm{p}=.00)$ had significant relationships with perceived alternatives. This suggests that higher ludics perceive more alternatives and higher erotics perceive fewer alternatives. 


\section{CHAPTER 5 RECOMMENDATIONS}

\section{Discussion}

Gerbner and Gross's (1973) Cultivation Theory posits the more a person watches television, the more they perceive it as the real world. Wober and Gunter (1988) expanded on this topic by hypothesizing it is not solely the amount of television one watches, but also the type of programming. Due to a lack of research regarding cultivation's effect on relational investments of communication, this study tested how Cultivation principles affected the Investment Model.

A higher amount of perceived alternatives were found to be correlated to a higher exposure to television dating shows. Interestingly, though television dating shows depict one individual's love being competed for by many, it did not cultivate beliefs that an individual's partner may feel the same. In others words, after watching television dating shows, individuals felt as if they had more alternatives to their relationship, however they did not perceive their partner to feel as if they had higher numbers of alternatives.

These correlations could be due to the fact that this study had such a large number of participants because the effect size is low. However, a low effect size can be still significant, statistically and practically. Though the effect size was low, it was statistically significant. This study can be seen as practically significant as well. Given that the Investment Model has been supported in the past (Rusbult, 1980, 1983), perceived alternatives do play a role in commitment to a romantic relationship. If the correlation exists, it could, in turn, affect commitment to the relationship in the long run. The results of this study were consistent with the Investment Model. Therefore, this correlation could play a part in commitment to a relationship. If this effect size loses commitment due to these high perceived alternatives as cultivated by these television 
dating shows, this could play a role in many relationships ending. Often romantic relationships will end due to one partner's will to end it. If only one partner cultivates these feelings, the effect is doubled, as this action would affect the partner as well. A subject of future research should be commitment to the relationship due to this effect.

Did the individual's love styles have an effect on the outcomes? It was found that only two love styles, Pragma and Mania, correlated with affinity for television dating shows. It was interesting to see that Ludus, those who view love as a game, were not correlated with higher affinity or exposure to television dating shows. Ludus lovers will tend to have various lovers at one time, and would seemingly identify with television dating shows. However, the data in the current study were not consistent with this idea. This could be a topic for future research. So why is it that Pragma, the practical lover, and Mania, the obsessed lover, nearly at opposite ends of the love style spectrum, both displayed affinity for television dating shows? It could be that, as a practical and logical being, the Pragma lovers are attracted to idea of a goal, or the idea of order to the love relationship. This can be seen in television dating shows, in that these shows have a weekly choice of who to keep and who to get rid of. There is a structure to this game. At the same time, these shows display individuals who quickly become obsessive over one person. From there, chaos erupts between those competing. This could explain the Mania lovers' attraction to television dating shows.

The results are consistent with both the Investment Model and Cultivation Theory. The length of the relationship was a significant factor on perceived alternatives, which would go hand in hand with investment in the relationship. The Investment Model states that as investment and satisfaction in a relationship are higher, often the perception of alternatives is lower (Rusbult, 
1980, 1983). Therefore, Investment Model hypotheses are again supported. Cultivation Theory has been supported, in part by this study.

Those who watched more reality television dating shows tended to perceive television as more real than others. Those who perceived television as more real believed themselves to have more perceived alternatives to their relationship. In general, those were exposed to more television dating shows identified themselves with the main characters and cultivated an idea that they had higher alternatives. Because exposure was correlated to a higher perception of alternatives, and no love style was correlated to exposure, it can be said that Cultivation Theory was supported, in a sense, in that there wasn't seen to be a specific type of lover that exposed themselves more to these shows. That means that no matter how individuals viewed love, higher exposure still led to higher perception of alternatives; consistent with Cultivation Theory. However, the perception of a partner having high alternatives was not seen to be cultivated by high exposure, which is inconsistent with Cultivation Theory. Individuals, if they believe themselves to have high alternatives as cultivated by these shows, should also have cultivated an idea that their partners would have higher alternatives. This was not the case.

Ludic lovers believed they had more perceived alternatives, which is consistent with the type of lover they are, believing love is a game. Eros lovers perceived less alternatives; this is also consistent as these are the passionate lovers.

What does this mean? Evidence suggests that reality television dating shows cultivate a higher perception of alternatives. What could this mean for the future? Future research can focus on many areas, especially how this finding may play into commitment to the relationship. Could these television shows create a similar effect to pornography (Zillman, 1986)? In other words, can one become addicted to these shows and how would that affect relationships? Certainly, 
future research can focus on relational outcomes due to these findings and even a neurological basis for the cultivation of higher perceived alternatives. What are the practical uses for this study? It may be plausible, to increase strength of the relationship, one should ignore high doses of reality television dating shows; at least at first. However, this could be a good topic for future research.

\section{Future Research}

Given that here, television has been shown to have a direct effect on relationships, where else and what other types of media could play a role in relational outcomes? Future research should focus on this. Future research should also focus on the role television and media play in creating norms for our culture. Is what Americans watch dictated by culture or is culture dictated by what Americans watch? The perceived alternatives of the partner should also be a topic of future research. How does this play into the Investment Model? This study found a significant negative correlation between partner's alternatives and commitment (See Appendix H). How do perceptions of partner's alternatives affect such issues as commitment? Can an individual's perception of their partner affect their commitment?

Due to the results found in this study, a natural step for future research would be to test those individuals who are exposed to high amounts of television dating shows' commitment to their romantic relationships. How does this effect change people's commitment to their relationship, if at all? Does this effect actually influence twice the amount of people's lives? Perhaps to fully understand this, one would have to study all other facets of the Investment Model as they pertain to this data, including how those who are exposed to high amounts of television dating shows view their relationship satisfaction, etc. Specifically, gathering a data set 
made entirely of those considered high exposure to television dating shows, and then testing these facets.

Overall, future research can look into the media's role in our construction of identity. Here, television had an effect on relational outcomes. What other aspects of the Investment Model can be affected by other media? How does this play a part in whom individuals become? Hecht, Collier, and Ribeau (1993) stated that one form of identity is relational identity, or who an individual is in respect to another. If, in the long run, perceived alternatives change our commitment levels, this can change our relational identity, and, therefore, our identity construction will have been affected by television. Does this occur in other arenas of media? If there is a relationship, how strong can it be?

\section{Limitations}

Some participants did not fully complete the online survey. No pretest was completed to determine who would be more willing to fill out the online survey, those who were e-mailed the link, or those who had the link posted to the online bulletin board. It may be possible that the Partner's Alternatives Scale was difficult to understand, as no pretest was run to determine its efficacy as well. In the future, a pretest will be run on this measure to determine it effectiveness. Conclusion

In sum, high exposure to television dating shows correlates to high amounts of perceived alternatives. In the long run, this could have major effects on relational outcomes, especially if this is supported in future research in other areas of media. Though it may not have been supported in this study, those feelings may need to be cultivated in individuals over a long time period, and be in concert with other variables to truly affect commitment. However, simply because it is found here that it can affect perceived alternatives, that in turn can affect 
commitment, which will change relational outcomes. In general, the more one watches television dating shows, the higher one perceives their alternatives. 


\section{References}

Attridge, M., \& Berscheid, E. (1994). Entitlement in romantic relationships in the United States: A Social Exchange perspective. In M. J. Lerner \& G. Mikula (Eds.), Entitlement and the affectional bond: Justice in close relationships (pp. 117-147). New York: Plenum Press.

Bevan, J. L. (2008). Experiencing and communicating romantic jealousy: Questioning the Investment Model. Southern Communication Journal, 73, 42-67.

Blau, P. M. (1964). Exchange and power in social life. New York: J. Wiley.

Borisoff, D., Hoel, P. C., \& McMahan, D. T. (2009). Interpersonal communication: Trajectories and challenges. In J. W. Chesebro (Ed.), A century of transformation: Studies in honor of the $100^{\text {th }}$ anniversary of the Eastern Communication Association (pp. 205-235). New York: Oxford.

Erikson, E. H. (1968) Identity: Youth and crisis. England: Norton \& Co.

Foster, J. D. (2008). Incorporating personality into the Investment Model: Probing commitment processes across individual differences in narcissism. Journal of Social and Personal Relationships, 25, 211-223.

Frey, K., \& Hojjat, M. (1998). Are love styles related to sexual styles? Journal of Sex Research, $35,265-271$.

Gerbner, G., \& Gross, L. (1973). Cultural indicators: The social reality of television drama (Report No. TM-002-990). Pennsylvania University, Philadelphia: Annenberg School of Communications. (ERIC Document Reproduction Service No. ED079390)

Guerrero, L. K., \& Bachman, G. F. (2008). Communication following relational transgressions in dating relationships: An Investment-Model explanation. Southern Communication Journal, 73, 4-23. 
Hecht, M., Collier, M. J., \& Ribeau, S. A. (1993). African American communication: Ethnic identity and cultural interpretation. Thousand Oaks, CA: Sage.

Hendrick, C., Hendrick, S. S., \& Dicke, A. (1998). The Love Attitudes Scale: Short form. Journal of Social and Personal Relationships, 15, 147-159.

Holmes, B. M. (2004). Romantic partner ideals and dysfunctional relationship beliefs cultivated through popular media messages: Implications for relationship satisfaction (Doctoral dissertation, University of Massachusetts, Amherst, 2004). Dissertation Abstracts International: Section B: The Sciences and Engineering, 65, 3222.

Johnson, M. K. (2007). Reality monitoring and the media. Applied Cognitive Psychology, 21, 981-993.

Kunkel, A., \& Burleson, B. (2003). Relational implications of communication skill evaluations and love styles. Southern Communication Journal, 68, 181-197.

Le, B., \& Agnew, C. R. (2003). Commitment and its theorized determinants: A meta-analysis of the Investment Model. Personal Relationships, 10, 37-57.

Levine, T., Aune, K. S., \& Park, H. S. (2006). Love styles and communication in relationships: Partner preferences, initiation, and intensification. Communication Quarterly, 54, 465486.

Nabi, R. L. (2009). Cosmetic surgery makeover programs and intentions to undergo cosmetic enhancements: A consideration of three models of media effects. Human Communication Research, 35, 1-27.

Rubin, A. M., Perse, E. M., \& Taylor, D. S. (1988). A methodological examination of cultivation. Communication Research, 15, 107-134. 
Rusbult, C. E. (1980). Commitment and satisfaction in romantic associations: A test of the Investment Model. Journal of Experimental Social Psychology, 16, 172- 186.

Rusbult, C. E. (1983). A longitudinal test of the Investment Model: The development (and deterioration) of satisfaction and commitment in heterosexual involvements. Journal of Personality and Social Psychology, 45, 101-117.

Rusbult, C. E., \& Buunk, B. P. (1993). Commitment processes in close relationships: An interdependence analysis. Journal of Social and Personal Relationships, 10, 175-204.

Rusbult, C. E., Johnson, D. J., \& Morrow, G. D. (1986). Predicting satisfaction and commitment in adult romantic involvements: An assessment of the generalizability of the Investment Model. Social Psychology Quarterly, 49, 81-89.

Rusbult, C. E., Martz, J. M., \& Agnew, C. R. (1998). The investment model scale: Measuring commitment level, satisfaction level, quality of alternatives, and investment size. Personal Relationships, 5, 357-391.

Rusbult, C. E., Zembrodt, I. M., \& Gunn, L. K. (1982). Exit, voice, loyalty, and neglect: Responses to dissatisfaction in romantic involvements. Journal of Personality and Social Psychology, 43, 1230-1242.

Sacher, J. A., \& Fine, M. A. (1996). Predicting relationship status and satisfaction after six months among dating couples. Journal of Marriage and the Family, 58, 21-32.

Scott, D. K., Gobetz, R. H., \& Chanslor, M. (2008). Chain versus independent television station ownership: Toward an investment model of commitment to local news quality. Communication Studies, 59, 84-98.

Segrin, C., \& Nabi, R. L. (2002). Does television viewing cultivate unrealistic expectations about marriage? Journal of Communication, 52, 247-263. 
Shapiro, J., \& Kroeger, L. (1991). Is life just a romantic novel? The relationship between attitudes about intimate relationships and the popular media. The American Journal of Family and Therapy, 19, 226-236.

Tuten, T. L. (2005). The effect of gay-friendly and non-gay-friendly cues on brand attitudes: A comparison of heterosexual and gay/lesbian reactions. Journal of Marketing Management, 21, 441-461.

Wober, M. \& Gunter, B. (1988). Television and social control. New York: St. Martin's Press.

Zillman, D. (1986). Effects of prolonged consumption of pornography. In E. P. Mulvey \& J. L. Haugaerd (Eds.) Report on the Surgeon General's workshop on pornography and public health. Washington, D. C.: U. S. Public Health Service and U. S. Department of Health and Human Services.

Zillman, D., \& Bryant, J. (1982). Pornography and sexual callousness, and the trivialization of rape. The Journal of Communication, 32(4), 10-21.

Zillman, D., \& Bryant, J. (1988). Pornography's impact on sexual satisfaction. Journal of Applied Social Psychology, 18, 438-453. 


\section{Appendix A}

How old are you?

Are you man or woman? man woman

Are you currently a:

Freshman

Sophomore

Junior

Senior

Other

How long have you been in your current romantic relationship? months

How would you describe this relationship?

What would you describe as your race?

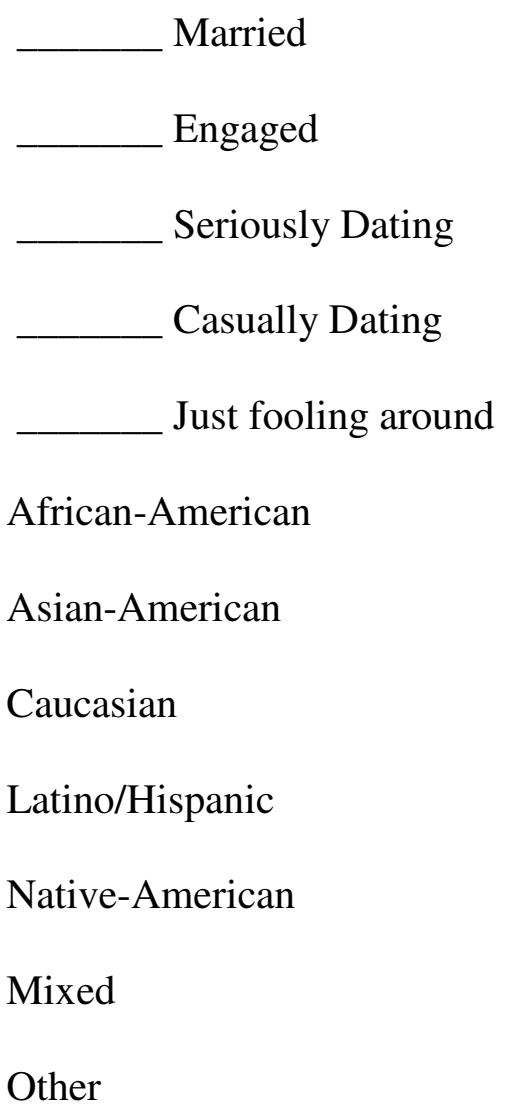




\section{Television Dating Show Scale I}

Affinity

1. I am a fan of television dating shows (Rock of Love, Flavor of Love, The Bachelor/Bachelorette, etc.)

\begin{tabular}{llccccr} 
Strongly Disagree & & Neutral & \multicolumn{2}{r}{ Strongly Agree } \\
1 & 2 & 3 & 4 & 5 & 6 & 7
\end{tabular}

2. I will seek out television dating shows to watch

\begin{tabular}{lrrrrrr} 
Strongly Disagree & & Neutral & \multicolumn{2}{r}{ Strongly Agree } \\
1 & 2 & 3 & 4 & 5 & 6 & 7
\end{tabular}

3. I will change the station when I see that a dating show is on next

\begin{tabular}{llccccr} 
Strongly Disagree & & Neutral & \multicolumn{2}{r}{ Strongly Agree } \\
1 & 2 & 3 & 4 & 5 & 6 & 7
\end{tabular}

4. I often find myself becoming attached to a main character on television dating shows

\begin{tabular}{lrcccrr} 
Strongly Disagree & & Neutral & \multicolumn{2}{r}{ Strongly Agree } \\
1 & 2 & 3 & 4 & 5 & 6 & 7
\end{tabular}

Exposure

5. I spend __ hours___ minutes watching television dating shows per week.

$\underline{\text { Involvement }}$

6. I do not pay attention to television dating shows while watching

\begin{tabular}{lrrrrrr} 
Strongly Disagree & & Neutral & \multicolumn{2}{r}{ Strongly Agree } \\
1 & 2 & 3 & 4 & 5 & 6 & 7
\end{tabular}


The Dating Game 28

7. I often find myself very interested in television dating shows

Strongly Disagree

1

2

3

Neutral

Strongly Agree

4

5

6

7 
Appendix B

Investment Model Scale (Rusbult, Martz, \& Agnew, 1998)

\section{$\underline{\text { Alternatives }}$}

My needs for intimacy (i.e., sharing personal thoughts, secrets, etc.) could be fulfilled in alternative relationships.

$\begin{array}{lllllllll}\text { Strongly Disagree } & 1 & 2 & 3 & 4 & 5 & 6 & 7 & \text { Strongly Agree }\end{array}$

My needs for companionship (i.e., doing things together, enjoying each other's company, etc.) could be fulfilled in alternative relationships.

$\begin{array}{lllllllll}\text { Strongly Disagree } & 1 & 2 & 3 & 4 & 5 & 6 & 7 & \text { Strongly Agree }\end{array}$

My sexual needs (i.e., holding hands, kissing etc.) could be fulfilled in alternative relationships.

$\begin{array}{lllllllll}\text { Strongly Disagree } & 1 & 2 & 3 & 4 & 5 & 6 & 7 & \text { Strongly Agree }\end{array}$

My needs for security (i.e., feeling trusting, feeling comfortable) could be fulfilled in alternative relationships.

$\begin{array}{lllllllll}\text { Strongly Disagree } & 1 & 2 & 3 & 4 & 5 & 6 & 7 & \text { Strongly Agree }\end{array}$

My needs for emotional involvement (i.e., feeling emotionally attached, feeling good when another feels good etc.) could be fulfilled in alternative relationships.

$\begin{array}{lllllllll}\text { Strongly Disagree } & 1 & 2 & 3 & 4 & 5 & 6 & 7 & \text { Strongly Agree }\end{array}$

The people other than my partner who I might become involved are very appealing.

$\begin{array}{lllllllll}\text { Strongly Disagree } & 1 & 2 & 3 & 4 & 5 & 6 & 7 & \text { Strongly Agree }\end{array}$

My alternatives to our relationship are close to ideal (dating another, spending time with friends, or on my own, etc.).

$\begin{array}{lllllllll}\text { Strongly Disagree } & 1 & 2 & 3 & 4 & 5 & 6 & 7 & \text { Strongly Agree }\end{array}$

If I weren't dating my partner, I would do fine - I would find another person to date.

$\begin{array}{lllllllll}\text { Strongly Disagree } & 1 & 2 & 3 & 4 & 5 & 6 & 7 & \text { Strongly Agree }\end{array}$

My alternatives are attractive to me (dating another, spending time with friends, or on my own, etc.). 
$\begin{array}{lllllllll}\text { Strongly Disagree } & 1 & 2 & 3 & 4 & 5 & 6 & 7 & \text { Strongly Agree }\end{array}$ My need for intimacy, companionship, etc., could be fulfilled in an alternative relationship.

$\begin{array}{lllllllll}\text { Strongly Disagree } & 1 & 2 & 3 & 4 & 5 & 6 & 7 & \text { Strongly Agree }\end{array}$

Commitment

I want our relationship to last for a very long time.

$\begin{array}{lllllllll}\text { Strongly Disagree } & 1 & 2 & 3 & 4 & 5 & 6 & 7 & \text { Strongly Agree }\end{array}$

I am committed to maintaining my relationship with my partner.

$\begin{array}{lllllllll}\text { Strongly Disagree } & 1 & 2 & 3 & 4 & 5 & 6 & 7 & \text { Strongly Agree }\end{array}$

I would not feel very upset if our relationship were to end in the near future.

$\begin{array}{lllllllll}\text { Strongly Disagree } & 1 & 2 & 3 & 4 & 5 & 6 & 7 & \text { Strongly Agree }\end{array}$

It is likely that I will date someone other than my partner within the next year.

$\begin{array}{lllllllll}\text { Strongly Disagree } & 1 & 2 & 3 & 4 & 5 & 6 & 7 & \text { Strongly Agree }\end{array}$

I feel very attached to our relationship and am very strongly linked to my partner.

$\begin{array}{lllllllll}\text { Strongly Disagree } & 1 & 2 & 3 & 4 & 5 & 6 & 7 & \text { Strongly Agree }\end{array}$

I want our relationship to last forever.

$\begin{array}{lllllllll}\text { Strongly Disagree } & 1 & 2 & 3 & 4 & 5 & 6 & 7 & \text { Strongly Agree }\end{array}$

I am oriented toward the long-term future of my relationship (e.g., I imagine being with my partner several years from now).

$\begin{array}{lllllllll}\text { Strongly Disagree } & 1 & 2 & 3 & 4 & 5 & 6 & 7 & \text { Strongly Agree }\end{array}$

Partner's Alternatives

I feel that my partner feels that their needs for intimacy (i.e., sharing personal thoughts, secrets, etc.) could be fulfilled in alternative relationships.

$\begin{array}{lllllllll}\text { Strongly Disagree } & 1 & 2 & 3 & 4 & 5 & 6 & 7 & \text { Strongly Agree }\end{array}$

I feel that my partner feels that their needs for companionship (i.e., doing things together, enjoying each other's company, etc.) could be fulfilled in alternative relationships. 
$\begin{array}{lllllllll}\text { Strongly Disagree } & 1 & 2 & 3 & 4 & 5 & 6 & 7 & \text { Strongly Agree }\end{array}$

I feel that my partner feels that their sexual needs (i.e., holding hands, kissing etc.) could be fulfilled in alternative relationships.

$\begin{array}{lllllllll}\text { Strongly Disagree } & 1 & 2 & 3 & 4 & 5 & 6 & 7 & \text { Strongly Agree }\end{array}$

I feel that my partner feels that their needs for security (i.e., feeling trusting, feeling comfortable) could be fulfilled in alternative relationships.

$\begin{array}{lllllllll}\text { Strongly Disagree } & 1 & 2 & 3 & 4 & 5 & 6 & 7 & \text { Strongly Agree }\end{array}$

I feel that my partner feels that their needs for emotional involvement (i.e., feeling emotionally attached, feeling good when another feels good etc.) could be fulfilled in alternative relationships.

$\begin{array}{lllllllll}\text { Strongly Disagree } & 1 & 2 & 3 & 4 & 5 & 6 & 7 & \text { Strongly Agree }\end{array}$

I feel that my partner feels that the people, other than myself, who they may become involved are very appealing.

$\begin{array}{lllllllll}\text { Strongly Disagree } & 1 & 2 & 3 & 4 & 5 & 6 & 7 & \text { Strongly Agree }\end{array}$

I feel that my partner feels that their alternatives to our relationship are close to ideal (dating another, spending time with friends, or on my own, etc.).

$\begin{array}{lllllllll}\text { Strongly Disagree } & 1 & 2 & 3 & 4 & 5 & 6 & 7 & \text { Strongly Agree }\end{array}$ I feel that my partner feels that if they weren't dating me, they would do fine - they would find another person to date.

$\begin{array}{lllllllll}\text { Strongly Disagree } & 1 & 2 & 3 & 4 & 5 & 6 & 7 & \text { Strongly Agree }\end{array}$

I feel that my partner feels that their alternatives are attractive to them (dating another, spending time with friends, or on my own, etc.).

$\begin{array}{lllllllll}\text { Strongly Disagree } & 1 & 2 & 3 & 4 & 5 & 6 & 7 & \text { Strongly Agree }\end{array}$

I feel that my partner feels that their need for intimacy, companionship, etc., could be fulfilled in an alternative relationship.

$\begin{array}{lllllllll}\text { Strongly Disagree } & 1 & 2 & 3 & 4 & 5 & 6 & 7 & \text { Strongly Agree }\end{array}$ 


\section{Appendix C}

\section{$\underline{\text { Love Attitudes Scale (Hendrick, Hendrick, \& Dicke, 1998) }}$}

Eros

1. My partner and I have the right physical "chemistry" between us.

$\begin{array}{lllllllll}\text { Strongly Disagree } & 1 & 2 & 3 & 4 & 5 & 6 & 7 & \text { Strongly Agree }\end{array}$

2. I feel that my partner and I were meant for each other.

$\begin{array}{lllllllll}\text { Strongly Disagree } & 1 & 2 & 3 & 4 & 5 & 6 & 7 & \text { Strongly Agree }\end{array}$

3. My partner and I really understand each other.

$\begin{array}{lllllllll}\text { Strongly Disagree } & 1 & 2 & 3 & 4 & 5 & 6 & 7 & \text { Strongly Agree }\end{array}$

4. My partner fits my ideal standards of physical beauty/handsomeness.

$\begin{array}{lllllllll}\text { Strongly Disagree } & 1 & 2 & 3 & 4 & 5 & 6 & 7 & \text { Strongly Agree }\end{array}$ Ludus

5. I believe that what my partner doesn't know about me won't hurt him/her.

$\begin{array}{lllllllll}\text { Strongly Disagree } & 1 & 2 & 3 & 4 & 5 & 6 & 7 & \text { Strongly Agree }\end{array}$

6. I have sometimes had to keep my partner from finding out about other lovers.

$\begin{array}{lllllllll}\text { Strongly Disagree } & 1 & 2 & 3 & 4 & 5 & 6 & 7 & \text { Strongly Agree }\end{array}$

7. My partner would get upset if he/she knew some of the things I've done with other people.

$\begin{array}{lllllllll}\text { Strongly Disagree } & 1 & 2 & 3 & 4 & 5 & 6 & 7 & \text { Strongly Agree }\end{array}$

8. I enjoy playing the "game of love" with my partner and a number of other partners.

$\begin{array}{lllllllll}\text { Strongly Disagree } & 1 & 2 & 3 & 4 & 5 & 6 & 7 & \text { Strongly Agree }\end{array}$


Storge

9. Our love is the best kind because it grew out of a long friendship.

$\begin{array}{lllllllll}\text { Strongly Disagree } & 1 & 2 & 3 & 4 & 5 & 6 & 7 & \text { Strongly Agree }\end{array}$

10. Our friendship merged gradually into love over time.

$\begin{array}{lllllllll}\text { Strongly Disagree } & 1 & 2 & 3 & 4 & 5 & 6 & 7 & \text { Strongly Agree }\end{array}$

11. Our love is a really deep friendship, not a mysterious, mystical emotion.

$\begin{array}{lllllllll}\text { Strongly Disagree } & 1 & 2 & 3 & 4 & 5 & 6 & 7 & \text { Strongly Agree }\end{array}$

12. Our love relationship is the most satisfying because it developed from a good friendship.

$\begin{array}{lllllllll}\text { Strongly Disagree } & 1 & 2 & 3 & 4 & 5 & 6 & 7 & \text { Strongly Agree }\end{array}$

Pragma

13. A main consideration in choosing my partner was how he/she would reflect on my family.

$\begin{array}{lllllllll}\text { Strongly Disagree } & 1 & 2 & 3 & 4 & 5 & 6 & 7 & \text { Strongly Agree }\end{array}$

14. An important factor in choosing my partner was if he/she would be a good parent.

$\begin{array}{lllllllll}\text { Strongly Disagree } & 1 & 2 & 3 & 4 & 5 & 6 & 7 & \text { Strongly Agree }\end{array}$

15. One consideration in choosing my partner was how he/she would reflect on my career.

$\begin{array}{lllllllll}\text { Strongly Disagree } & 1 & 2 & 3 & 4 & 5 & 6 & 7 & \text { Strongly Agree }\end{array}$

16. Before getting very involved with my partner, I tried to figure out how compatible his/her hereditary background would be with mine in case we ever had children.

$\begin{array}{lllllllll}\text { Strongly Disagree } & 1 & 2 & 3 & 4 & 5 & 6 & 7 & \text { Strongly Agree }\end{array}$

Mania

17. When my partner doesn't pay attention to me, I feel sick all over.

$\begin{array}{lllllllll}\text { Strongly Disagree } & 1 & 2 & 3 & 4 & 5 & 6 & 7 & \text { Strongly Agree }\end{array}$ 
18. Since I've been in love with my partner I've had trouble concentrating on anything else.

$\begin{array}{lllllllll}\text { Strongly Disagree } & 1 & 2 & 3 & 4 & 5 & 6 & 7 & \text { Strongly Agree }\end{array}$

19. I cannot relax if I suspect that my partner is with someone else.

$\begin{array}{lllllllll}\text { Strongly Disagree } & 1 & 2 & 3 & 4 & 5 & 6 & 7 & \text { Strongly Agree }\end{array}$

20. If my partner ignores me for awhile, I sometimes do stupid things to try to get his/her attention back.

$\begin{array}{lllllllll}\text { Strongly Disagree } & 1 & 2 & 3 & 4 & 5 & 6 & 7 & \text { Strongly Agree }\end{array}$

Agape

21. I would rather suffer myself than let my partner suffer.

$\begin{array}{lllllllll}\text { Strongly Disagree } & 1 & 2 & 3 & 4 & 5 & 6 & 7 & \text { Strongly Agree }\end{array}$

22. I cannot be happy unless I place my partner's happiness before my own.

$\begin{array}{lllllllll}\text { Strongly Disagree } & 1 & 2 & 3 & 4 & 5 & 6 & 7 & \text { Strongly Agree }\end{array}$

23. I am usually willing to sacrifice my own wishes to let my partner achieve his/hers.

$\begin{array}{lllllllll}\text { Strongly Disagree } & 1 & 2 & 3 & 4 & 5 & 6 & 7 & \text { Strongly Agree }\end{array}$

24. I would endure all things for the sake of my partner.

$\begin{array}{lllllllll}\text { Strongly Disagree } & 1 & 2 & 3 & 4 & 5 & 6 & 7 & \text { Strongly Agree }\end{array}$




\section{Appendix D}

\section{Perceived Reality Scale (Rubin, Perse, \& Taylor, 1988)}

1. Television shows life as it really is.

$\begin{array}{lllllllll}\text { Strongly Disagree } & 1 & 2 & 3 & 4 & 5 & 6 & 7 & \text { Strongly Agree }\end{array}$

2. Television presents things as they really are in life.

$\begin{array}{lllllllll}\text { Strongly Disagree } & 1 & 2 & 3 & 4 & 5 & 6 & 7 & \text { Strongly Agree }\end{array}$

3. If I see something on television I can be sure it really is that way.

$\begin{array}{lllllllll}\text { Strongly Disagree } & 1 & 2 & 3 & 4 & 5 & 6 & 7 & \text { Strongly Agree }\end{array}$

4. Television lets me see how other people live.

$\begin{array}{lllllllll}\text { Strongly Disagree } & 1 & 2 & 3 & 4 & 5 & 6 & 7 & \text { Strongly Agree }\end{array}$

5. Television lets me see what happens in other places as if I'm really there.

$\begin{array}{lllllllll}\text { Strongly Disagree } & 1 & 2 & 3 & 4 & 5 & 6 & 7 & \text { Strongly Agree }\end{array}$


Appendix E

Correlations Between Various Alternatives Scales and Exposure

Perceives Alternatives Perceived Partner's Alternatives

Exposure

$.13 *$

.04

Note: * Denotes correlation statistically significant at $p<.05$. 


\section{Appendix F}

\begin{tabular}{lcccccc}
\hline \multicolumn{6}{l}{ Correlations Between Love Styles and Exposure and Affinity/Involvement } \\
\hline & Eros & Ludus & Storge & Pragma & Manic & Agape \\
\hline Exposure & -.02 & .11 & .03 & .11 & .11 & -.05 \\
Affinity/Involvement & -.03 & .05 & .07 & $.17^{*}$ & $.24^{* *}$ & .03 \\
& & & & & & \\
\hline
\end{tabular}

Note: $*$ Denotes correlation statistically significant at $p<.05$; and $* * p<.01$. 


\section{Appendix G}

Significant Variables Accounting for Variance in Perceived Alternatives

\begin{tabular}{ll}
\hline & $\beta$ \\
\hline Exposure & $.13^{*}$ \\
Seriousness of Relationship & $-.19^{* *}$ \\
Perceived Reality of Television & $.11^{*}$ \\
Ludus Love Style & $.27^{* *}$ \\
Eros Love Style & $-.32^{* *}$ \\
\hline
\end{tabular}

Note: $*$ Denotes correlation statistically significant at $p<.05$; and $* * p<.01$. 


\section{Appendix $\mathrm{H}$}

\section{Correlation Matrix of All Variables}
(1) (2)
(3)
(4)
(5)
(6)
(7) (8)
(9) (10) (11)

1. Eros

2. Ludus

$-.35^{* *} \quad-$

3. Storge

$.26^{* *}-.11 \quad-$

4. Pragma

$.13^{*} \quad .02 \quad .33^{* *} \quad-$

5. Manic

$\begin{array}{lll}-.04 & .18^{* *} .07 \quad .37^{* *}-\end{array}$

6. Agape

$.36^{* *}-.18^{* *} .23^{* *} \quad .25^{* *} .35^{* *}-$

7. Exposure

$\begin{array}{lllllll}-.02 & .11 & .03 & .11 & .11 & -.05 & -\end{array}$

8. Affinity

$\begin{array}{llllllll}-.03 & .05 & .07 & .17 * * & .24 * * & .03 & .27 * * & -\end{array}$

9. Alternatives

$-.52 * * .47 * * .14 *-.13 * * \quad .04 \quad-.26 * * .13 * \quad .09 \quad-$

10. Partner's

$\begin{array}{llllllll}-.48^{* *} & .28 * *-.10 & -.04 & .18^{* *}-.11 & .04 & .08 & .63^{* *} & -\end{array}$

11. Commitment

$$
.72 * *-.40 * * .22 * * .18 * *-.02
$$$$
.35^{* *}-.06 \quad-.00 \quad-.57 * *-.51 * * \quad-
$$

Note: $*$ Denotes correlation statistically significant at $p<.05$; and $* * p<.01$. 


\author{
Thomas L. Meade \\ Graduate Teaching Assistant, West Virginia University \\ Morgantown, WV 26505 \\ tmeade4@gmail.com \\ Vita \\ Bachelor of Science, Journalism (Advertising) \\ West Virginia University \\ Cum Laude \\ Master of Arts, Communication Studies \\ West Virginia University
}

2007

In Progress

\title{
PROFESSIONAL EXPERIENCE
}

2008-09

Graduate Teaching Assistant

- Assisted with sections of Communication 122:

Communication in Contemporary Society, and

Communication 308: Nonverbal Communication

- Responsibilities: Managing nearly a thousand students' grades, tests, papers, essays, attendance, and extra credit activities, also managed undergraduate teaching assistants.

\section{GRADUATE COURSES}

Fall 2008

Communication 793D: Foundations of Communication

Communication 602: Interpersonal Communication

Theory/Research

Communication 629: Health Communication

Communication 700: Survey of Human Communication Theory 
Communication 701: Graduate Research Methods

Spring 2009

Communication 509: Health Communication Dissemination

Communication 625: Computer Mediated Communication

Communication 697: Research (Thesis)

Communication 713: Qualitative Research Methods

Communication 794M: Communication Meta-Theory

Summer 2009

Communication 604: Theory/Research in Persuasion

Communication 697: Research (Thesis)

\section{PAPERS IN PUBLICATION SUBMISSION PROCESS}

Staggers, S. M., Martin, M. M., Allara, L. K., Coughenour, J. D., Malachowski, C. C., \& Meade, T. L. (revising analyses for publication purposes). Guarded with Gardasil: A reasoned action approach toward the HPV vaccination.

Meade, T. L., Ward, D. M., \& Booth-Butterfield, M. (2009). Physical Fitness? Attitudes, norms, beliefs, and volitional control when cleaning gym equipment. Manuscript in preparation, West Virginia University.

Meade, T. L., Schulte, J. M., \& Brann, B. M. (2009). Do facial features affect perceptions and communication? Manuscript in preparation, West Virginia University.

Meade, T. L., \& Westerman, D. (2009). The dating game: Cultivation effects on relational investment. Manuscript in preparation, West Virginia University. 


\section{CONFERENCE PRESENTATIONS}

Staggers, S. M., Allara, L. K., Coughenour, J. D., Malachowski, C., \& Meade, T. L. (2009, April). The Theory of Reasoned Action and college students' HPV vaccinations. Paper presented at the annual meeting of the Eastern Communication Association Convention, Philadelphia, PA.

\footnotetext{
Digitally signed by John $\mathrm{H}$. Hagen $\mathrm{DN}: \mathrm{cn}=$ John $\mathrm{H}$. Hagen, o=West 